medRxiv preprint doi: https://doi.org/10.1101/2020.12.17.20248437; this version posted December 19, 2020. The copyright holder for this preprint (which was not certified by peer review) is the author/funder, who has granted medRxiv a license to display the preprint in perpetuity.

It is made available under a CC-BY-ND 4.0 International license .

\title{
Detection of SARS-CoV2 antigen in human saliva may be a reliable tool for large scale screening
}

Priya Kannian ${ }^{1 *}$, Chandra Lavanya ${ }^{2}$, Krittika Ravichandran $^{3}$, Bagavad Gita Jayaraman $^{3}$, Pasuvaraj Mahanathi ${ }^{1}$, Veeraraghavan Ashwini ${ }^{1}$, Nagalingeswaran Kumarasamy ${ }^{4}$, Gunaseelan Rajan $^{3}$, Kannan Ranganathan ${ }^{2}$, Stephen J. Challacombe ${ }^{5}$, Jennifer Webster-Cyriaque ${ }^{6}$, Newell W. Johnson $2,3,5,7$

${ }^{1}$ VHS Laboratory Services, Department of Clinical Research, VHS Hospital, Chennai, India ${ }^{2}$ Department of Oral Pathology, Ragas Dental College and Hospital, Chennai, India

${ }^{3}$ Chennai Dental Research Foundation, Chennai, India ${ }^{4}$ VHS-Infectious Diseases Medical Centre, VHS Hospital, Chennai, India

${ }^{5}$ Faculty of Dentistry \& Craniofacial Sciences, King's College London, UK ${ }^{6}$ University of North Carolina, Chapel Hill, USA

${ }^{7}$ Menzies Health Institute Queensland, Griffith University, Queensland, Australia

Address for Correspondence:

* Dr. Priya Kannian

Scientist \& Head

Department of Clinical Research

VHS Hospital

Rajiv Gandhi Salai

Taramani, Chennai - 600113

Tamil Nadu, India

Ph: 91-44-22541972

Email: priyakannian@gmail.com

Word counts: Abstract - 181; Text - 1069 
medRxiv preprint doi: https://doi.org/10.1101/2020.12.17.20248437; this version posted December 19, 2020. The copyright holder for this preprint (which was not certified by peer review) is the author/funder, who has granted medRxiv a license to display the preprint in perpetuity.

It is made available under a CC-BY-ND 4.0 International license .

\section{Abstract}

2 Introduction: SARS-CoV2, the aetiological agent of the current COVID-19 pandemic, has

3 been detected in saliva and recently implicated in several oral diseases. Collection of

4 nasopharyngeal swabs (NPS) and detection by reverse transcriptase-polymerase chain reaction

5 (RT-PCR) requires medical / technical expertise. A reliable and easy to handle point-of-care

6 (POC) test is highly desirable, especially to curb transmission. Therefore, in this study, we

7 evaluated a commercially available POC rapid antigen test (RAT) for the detection of SARS-

8 CoV2 antigens in the saliva of RT-PCR confirmed positive and negative patients. Methods:

9 Thirty saliva samples of 10 saliva RT-PCR negative and 20 saliva RT-PCR positive patients

10 were tested by RAT. Results: RAT was negative in 10/10 (100\%) RT-PCR-negative samples;

11 positive in 9/20 (45\%) RT-PCR-positive samples; concordance was $63 \%(\mathrm{p}=0.001)$. Patients

12 with positive RAT had higher virus copies in their NPS samples compared to the RAT-negative

13 patients. This difference was also statistically significant $(\mathrm{p}=0.01)$. Conclusion: Thus, the POC

14 RAT may be used to detect SARS-CoV2 as a reliable tool for self-testing, large-scale population

15 screening and emergency medical/dental screening. Patients negative by RAT should be

16 confirmed by RT-PCR.

17

18 Keywords: SARS-CoV2, saliva, rapid antigen test, RT-PCR 
medRxiv preprint doi: https://doi.org/10.1101/2020.12.17.20248437; this version posted December 19, 2020. The copyright holder for this preprint (which was not certified by peer review) is the author/funder, who has granted medRxiv a license to display the preprint in perpetuity.

It is made available under a CC-BY-ND 4.0 International license .

\section{Text}

2 COVID-19, the current pandemic, is caused by SARS-CoV2, a respiratory RNA virus.

3 Respiratory viruses are transmitted through secretions from the respiratory tract that are

4 dispersed within close contacts. SARS-CoV2 primarily infects the epithelial and endothelial

5 cells lining the respiratory mucosae and the ducts of minor mucous glands. A number of

6 different respiratory tract samples, including nasopharyngeal swab (NPS), sputum, bronchial

7 aspirate and bronchoalveolar lavage have been tested for the detection of SARS-CoV2 RNA [1].

8 The NPS rapidly became the favored sample, as it retrieves cells from a site where the virus

9 perpetuates with minimal risk of transmission through aerosols [2]. However, collection of NPS

10 is somewhat invasive and causes discomfort; it requires medical/technical expertise, which might

11 not be available in remote villages, especially in developing countries like India. On the other

12 hand, epithelial cells of the oral mucosa and particularly the ducts of the minor salivary glands,

13 have been shown to carry large numbers of angiotensin converting enzyme-2 (ACE-2) receptors

14 that bind the SARS-CoV2 virus [3,4]. Symptoms such as loss of taste and smell, xerostomia and

15 oral ulcerations have been increasingly reported with COVID-19 pointing to salivary

16 transmission of the SARS-CoV2 virus [5]. Further there is increasing evidence to date pointing

17 to the involvement of the salivary gland by itself in COVID-19 with acute parotitis being

18 commonly reported [6].

20 Saliva is now accepted as an ideal diagnostic fluid for numerous diseases, including

21 cardiovascular diseases and several cancers, with detectable levels of antibodies, antigens, DNA,

22 RNA and microorganisms, with sensitivities and specificities comparable to serum [8]. This

23 combined with its non-invasive method of self-collection, which does not require technical 
medRxiv preprint doi: https://doi.org/10.1101/2020.12.17.20248437; this version posted December 19, 2020. The copyright holder for this preprint (which was not certified by peer review) is the author/funder, who has granted medRxiv a license to display the preprint in perpetuity.

It is made available under a CC-BY-ND 4.0 International license .

1 expertise and has less risk of disease transmission, makes saliva an attractive choice as a

2 diagnostic specimen $[9,10]$. Early and quick detection of SARS-CoV2 is of prime importance in

3 containing its spread. Most rapid antigen kits in commercial use are based on NPS specimens.

4 In this study we evaluated the utility of a SARS-CoV2 antigen kit using drooled saliva samples

5 from laboratory-confirmed SARS-CoV2 RT-PCR positive patients.

7 The study was approved by the VHS-Institutional Ethics Committee (proposal \#: VHS-IEC/69-

8 2020). Saliva samples from 30 patients previously tested for SARS-CoV2 by RT-PCR in their

9 NPS and saliva (collected simultaneously from the out-patients of the COVID clinic and in-

10 patients of the COVID wards, VHS Hospital, Chennai, India) were selected retrospectively in an

11 anonymous delinked manner. Ten saliva samples negative by RT-PCR (5 NPS-positive and 5

12 NPS-negative) were selected as controls. Twenty saliva samples from patients with NPS and

13 saliva positivity by RT-PCR were selected as test samples. The presence of SARS-CoV2

14 antigen was tested using the Indian Council of Medical Research (ICMR) validated (for NPS

15 samples) commercially available rapid lateral flow kit (SD Biosensor, Korea) [11]. Three

16 hundred microliters of free-flowing saliva without any mucous material was mixed with the

17 extraction buffer (provided in the kit). The test was performed as per the manufacturer's

18 instructions. The viral copy numbers in the NPS samples were extrapolated from the Ct (cycle

19 threshold) values using the standard curve equation generated from commercially available

20 SARS-CoV2 RNA standards of $N$ gene and RdRp gene (Exact Diagnostics, USA). Median and

21 interquartile ranges were calculated using Microsoft excel. The Mann-Whitney rank sum test

22 and McNemar tests were performed using free online calculators. 
medRxiv preprint doi: https://doi.org/10.1101/2020.12.17.20248437; this version posted December 19, 2020. The copyright holder for this preprint (which was not certified by peer review) is the author/funder, who has granted medRxiv a license to display the preprint in perpetuity.

It is made available under a CC-BY-ND 4.0 International license .

1 All 10 RT-PCR negative saliva samples were negative for the presence of SARS-CoV2 antigens.

2 Of the 20 RT-PCR positive saliva samples, 9 (45\%) were positive. The sensitivity, specificity

3 and concordance for the saliva antigen test were calculated against the saliva RT-PCR test. True

4 positives were 9/20 (45\%). True negatives were 10/10 (100\%). Therefore, the sensitivity was

$545 \%$, specificity $100 \%$ and concordance $63 \%$ : the last being statistically significant $(\mathrm{p}=0.001$;

6 McNemar test). Antigen detection is generally less sensitive than RT-PCR. So, we compared

7 the SARS-CoV2 copies in the NPS of the patients with a negative or positive antigen test. The

8 median and interquartile range of the virus copies were markedly higher among the antigen

9 positive patients (Figure 1) and this difference was statistically significant ( $\mathrm{p}=0.01$; Mann

10 Whitney rank sum test).

12 Our data show that the point-of-care SARS-CoV2 antigen lateral flow test can detect the

13 presence or absence of the virus in the saliva in $63 \%$ of the cases in a reliable manner.

14 Additionally, the majority of the patients who were SARS-CoV2 antigen positive in their saliva

15 samples had higher viral copies than those who were antigen negative. A similar result was

16 shown by Nagura-Ikeda et al, although the sensitivity of their rapid antigen test was only $11.7 \%$

17 [12]. This difference in sensitivities could be attributed to the difference in testing methods. We

18 have added free-flowing saliva directly to the extraction buffer. Nagura-Ikeda et al have dipped

19 a cotton swab in the saliva sample, which was then dipped into the extraction buffer [12]. The

20 cotton swab would have absorbed the liquid from the saliva with minimal absorption of virions

21 and virus-infected cells thereby resulting is much less sensitivity. RT-PCR is a highly sensitive

22 method that detects the presence of viral RNA by million-fold amplification. RNA from dead

23 virus or unpackaged RNA will also be picked up by the RT-PCR. On the other hand, the antigen 
medRxiv preprint doi: https://doi.org/10.1101/2020.12.17.20248437; this version posted December 19, 2020. The copyright holder for this preprint (which was not certified by peer review) is the author/funder, who has granted medRxiv a license to display the preprint in perpetuity.

It is made available under a CC-BY-ND 4.0 International license .

1 test has moderate sensitivity due to the lack of any kind of amplification and detects the

2 translated proteins of the virus. Therefore, antigen positivity denotes abundance of proteins and

3 in turn high copy numbers as shown in the figure. The limitation in the use of saliva samples is

4 the requirement of a diligently collected free-flowing drooled sample without any sputum

5 contamination, as the thick phlegm/mucous can compromise the free lateral flow of the sample

6 across the chromatogram causing false negative results.

8 Overall, the point-of-care antigen test may be used for the detection of SARS-CoV2 in saliva

9 samples for the rapid confirmation in symptomatic cases requiring urgent medical care. In post-

10 treatment or post-quarantine people this test might be very useful to rule out risk of transmission,

11 given that RT-PCR can remain positive for up to three months. Since this is a rapid, easy to use

12 point-of-care test it can also be advocated to be used at home as a self-test. It would also be

13 useful before invasive procedures, especially in dentistry, to assess the risk of transmission or in

14 small remote medical centres where medical expertise to collect NPS samples and technical

15 expertise for RT-PCR are often not available. The small group of antigen-negative people may

16 be confirmed by collecting NPS samples and transporting to higher facilities for RT-PCR.

18 Acknowledgements: This work was funded by intramural research funds of Chennai Dental

19 Research Foundation, Chennai, India.

\section{Abbreviations}

22 SARS-CoV2 severe acute respiratory syndrome - coronavirus 2

23 COVID-19 coronavirus disease 2019 
medRxiv preprint doi: https://doi.org/10.1101/2020.12.17.20248437; this version posted December 19, 2020. The copyright holder for this preprint (which was not certified by peer review) is the author/funder, who has granted medRxiv a license to display the preprint in perpetuity.

It is made available under a CC-BY-ND 4.0 International license .

1 RT-PCR reverse transcriptase-polymerase chain reaction

2 NPS nasopharyngeal swab

3 POC point-of-care

4 RAT rapid antigen test

5 ACE-2 angiotensin converting enzyme-2

6 ICMR Indian Council of Medical Research

8 References

9 [1] W. Wang, Y. Xu, R. Gao, R. Lu, K. Han, G. Wu, W. Tan, Detection of SARS-CoV-2 in

10 Different Types of Clinical Specimens, JAMA. $323 \quad$ (2020) 1843-1844.

11 https://doi.org/10.1001/jama.2020.3786.

12

13 [2] Overview of testing for SARS-CoV-2 (COVID-19). National Center for Immunization and

14 Respiratory Diseases (NCIRD), Division of Viral Diseases Oct (2020).

15 https://www.cdc.gov/coronavirus/2019-ncov/hcp/testing-overview.

16

17 [3] H. Xu, L. Zhong, J. Deng, J. Peng, H. Dan, X. Zeng, T. Li, Q. Chen, High expression of

18 ACE2 receptor of 2019-nCoV on the epithelial cells of oral mucosa, Int. J. Oral. Sci. 12 (2020)

19 8. https://doi.org/10.1038/s41368-020-0074-x.

20

21 [4] L. Huang, P. Perez, T. KatoN. Huang, P. Perez , T. Kato, Y. Mikami, K. Okuda, R. C.

22 Gilmore, C. D. Conde, B. Gasmi, S. Stein, M. Beach, E. Pelayo, J. Maldonado, B. LaFont, R.

23 Padilla , V. Murrah, R. Maile, W. Lovell, S. Wallet, N. M. Bowman, S. L Meinig, M.C. 
medRxiv preprint doi: https://doi.org/10.1101/2020.12.17.20248437; this version posted December 19, 2020. The copyright holder for this preprint (which was not certified by peer review) is the author/funder, who has granted medRxiv a license to display the preprint in perpetuity.

It is made available under a CC-BY-ND 4.0 International license .

1 Wolfgang, S. N. Choudhury, M. Novotny, B. D. Aevermann, R. Scheuermann, G. Cannon, C.

2 Anderson, J. Marchesan, M. Bush, M. Freire, A. Kimple, D. L. Herr, J. Rabin, A. Grazioli, B. N.

3 French, T. Pranzatelli, J. A. Chiorini, D. E. Kleiner, S. Pittaluga, S. Hewitt, P. D. Burbelo, D.

4 Chertow, NIH COVID-19 Autopsy Consortium, HCA Oral and Craniofacial Biological

5 Network, K. Frank, J. Lee, R. C. Boucher, S. A. Teichmann, B. M. Warner, K. M. Byrd,

6 Integrated Single-Cell Atlases Reveal an Oral SARS-CoV-2 Infection and Transmission Axis,

7 MedrXiv. October 29 (2020). https://doi.org/10.1101/2020.10.26.20219089.

9 [5] L. Chen, J. Zhao, J. Peng, X. Li, X. Deng, Z. Geng, Z. Shen, F. Guo, Q. Zhang, Y. Gin, L.

10 Wang, S. Wang, Detection of SARS-CoV-2 in saliva and characterization of oral symptoms in

11 COVID-19 patients, Cell. Prolif. 53 (2020) e12923. https://doi.org/10.1111/cpr.12923.

12

13 [6] A. Riad, I. Kassem, M. Badrah, M. Kluger. Acute parotitis as a presentation of

14 COVID $\square$ 19?, Oral. Diseases. 00 (2020) 1-2. https://doi.org/10.1111/odi.13571.

16 [7] D. Malamud, I. R. Rodriguez-Chavez, Saliva as a Diagnostic Fluid, Dental. Clin. North. Am. 17 55(2011) 159-178. https://doi.org/10.1016/j.cden.2010.08.004.

19 [8] L. Azzi, G. Carcano and F. Gianfagna. P. Grossi, D. D. Jasperina, A. Genoni, M. Fasano, F.

20 Sessa, L. Tettamanti, F. Carinci, V. Maurino, A. Rossi, A. Tagliabue, A. Baj, Saliva is a reliable 21 tool to detect SARS-CoV-2, J. Infect. $81 \quad$ (2020) e45-e50.

22 https://doi.org/10.1016/j.jinf.2020.04.005. 
medRxiv preprint doi: https://doi.org/10.1101/2020.12.17.20248437; this version posted December 19, 2020. The copyright holder for this preprint (which was not certified by peer review) is the author/funder, who has granted medRxiv a license to display the preprint in perpetuity. It is made available under a CC-BY-ND 4.0 International license .

1 [9] K.K. To, O. T. Tsang, C. C. Y. Yip, K. H. Chan, T. C. Wu, J. M. Chan, W. Leung, T. S.

2 Chik, C. Y. Choi, D. H. Kandamby, D. C. Lung, A. R. Tam, R. W. Poon, A. Y. Fung, I. F. Hung,

3 V. C. Cheng, J. F. Chan, K. Yuen, Consistent detection of 2019 novel coronavirus in saliva, Clin.

4 Infect. Dis. 71 (2020) 841-843. https://doi.org/10.1093/cid/ciaa149.

6 [10] F. Cerutti, E. Burdino, M.G. Milia, T. Allice, G. Gregori, B. Bruzzone, V. Ghisetti, Urgent

7 need of rapid tests for SARS-CoV2 antigen detection: Evaluation of the SD-Biosensor antigen

8 test for SARS-CoV2, J. Clin. Virol. 132 (2020): 104654. https://doi.org/10.1016/j.jcv.2020. 9104654.

11 [11] M. Nagura-Ikeda, K. Imai, S. Tabata, K. Miyoshi, N. Murahara, T. Mizuno, M. Horiuchi,

12 K. Kato, Y. Imoto, M. Iwata, S. Mimura, T. Ito, K. Tamura, Y. Kato, Clinical Evaluation of Self-

13 Collected Saliva by Quantitative Reverse Transcription-PCR (RT-qPCR), Direct RT-qPCR,

14 Reverse Transcription-Loop-Mediated Isothermal Amplification, and a Rapid Antigen Test To

15 Diagnose COVID-19, J. Clin. Microbiol. $58 \quad$ (2020) e1438-20.

16 https://doi.org/10.1128/JCM.01438-20. 
medRxiv preprint doi: https://doi.org/10.1101/2020.12.17.20248437; this version posted December 19, 2020. The copyright holder for this preprint (which was not certified by peer review) is the author/funder, who has granted medRxiv a license to display the preprint in perpetuity. It is made available under a CC-BY-ND 4.0 International license .

\section{Figure legends}

2

3 Figure 1: Patients with positive saliva antigen test have higher SARS-CoV2 copies in the

$4 \quad$ NPS samples. X-axis denotes negative and positive categories of the saliva antigen test. Y-axis

5 denotes the number of SARS-CoV2 copies. The interquartile range shows the $25-75 \%$ range of

6 the virus copies in each category. The error bars depict the minimum and maximum copy

7 numbers in each category.

8

9

10

11

12 


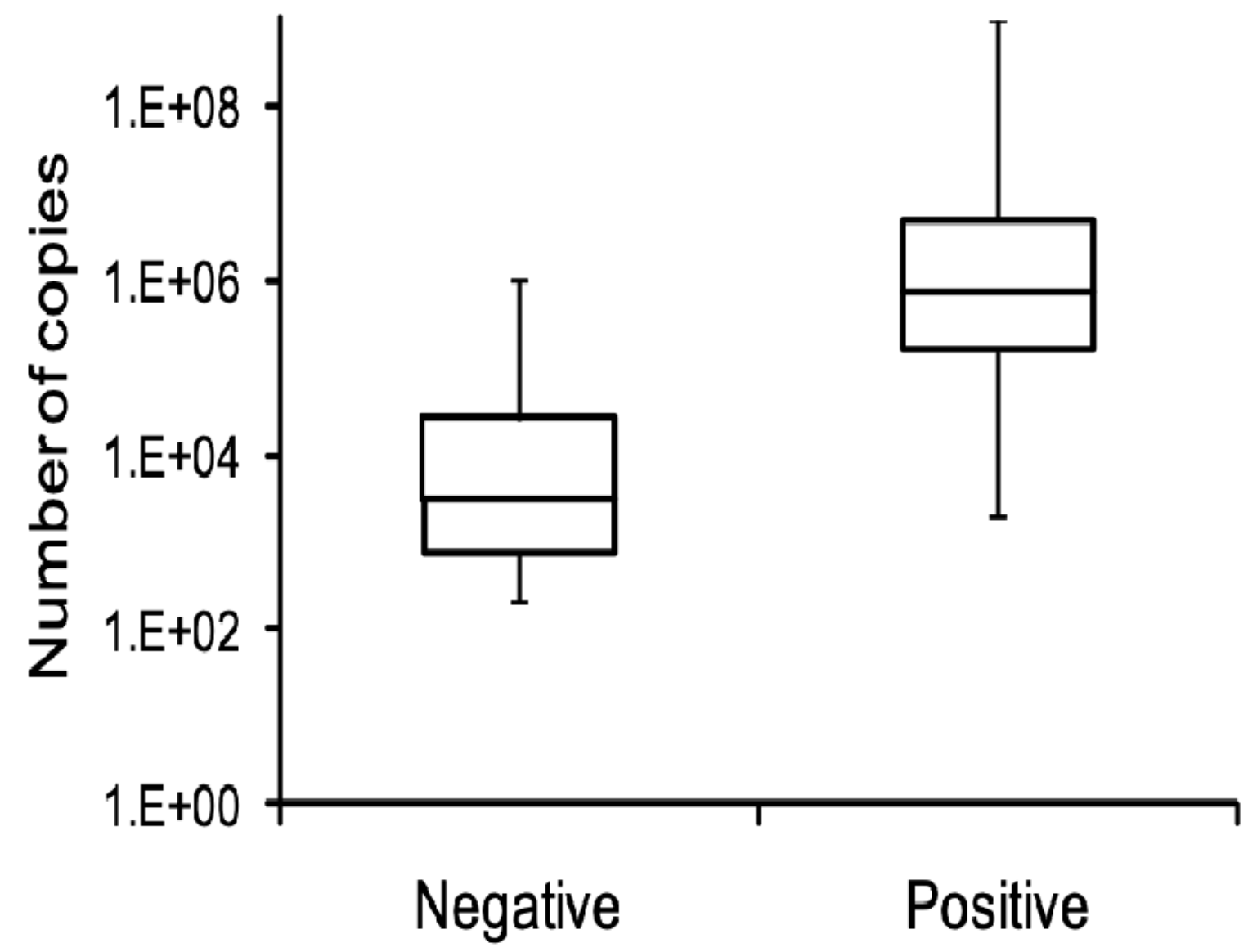

Figure 1 